\title{
Effect of Ginger's (Zingiber officinale) Aqueous Extract on Characteristics of Transglutaminase Mediated Sausages from Thai Pangas (Pangasianodon hypophthalamus) Surimi During Refrigerated Storage
}

\author{
Ranendra K Majumdar $^{1 *}$, Apurba Saha ${ }^{2}$, Pradip K Maurya ${ }^{2}$, Amjad K Balange $^{2}$, Snehal Shitole ${ }^{2}$ and Deepayan \\ Roy $^{1}$
}

${ }^{1}$ Central Agricultural University, India

${ }^{2}$ Central Institute of Fisheries Education, India

Submission: March 01, 2017; Published: May 30, 2017

*Corresponding author: Ranendra K Majumdar, College of Fisheries (Central Agricultural University), Lembucherra, Tripura-799210, India, Tel: +919862441057; Fax: +91381-2865-291; Email: drrkmcof@gmail.com

\begin{abstract}
The effect of ginger's aqueous extract (GAE) during refrigerated storage of the restructured products from Pangasius (Pangasianodon hypophthalmus) was evaluated. Protein and lipid oxidation, protein pattern, TPC as well as WHC, gelling properties, texture profiles and whiteness of the surimi gel was evaluated periodically during a refrigerated storage period of 20 days. Increase of water holding capacity in GAE added gels indicated stronger protein network formation, whereas, decrease of protein solubility suggested formation of protein aggregates during gelation. Lipid oxidation decreased in treated samples but the rate of increase varied, depending upon the concentration of GAE. Protein carbonyl increased during storage, but slowly in treated samples. Gel strength in treated samples increased and accompanied by thickening of myofibrillar head chain. Hardness, adhesiveness and gumminess parameters affected most due to addition of GAE. Sensory analysis revealed that the sausage with $1 \%$ GAE preferred most and control was acceptable up to 16 days.

Keywords: Pangasiusl; Sausage; Ginger; Protein oxidation; Lipid oxidation

Practical Application

In order to avoid any chemical gel enhancer or preservative for checking lipid oxidation in sausage type of products, use of microbial trans glutaminase and natural antioxidant rich spice like ginger is a good option. From consumers' acceptance point of view this type of products would fetch a level of consumers in city and big towns who are health conscious.
\end{abstract}

\section{Introduction}

Lipid oxidation is considered as a major cause of deterioration of muscle food which ultimately affect colour, flavour, texture and nutritional value of food. Lipid peroxidation and resultant lipid degraded products pose a great concern in respect of safety of fish and fish products. Oxidation thus limits the storage time and thereby also affects the marketing of both fish and meat products. Lipid oxidized products, particularly aldehydes, can react with specific amino acids to form carbonyls [1]. These can also interact with protein aggregates [2], causing additional nutritional losses. Antioxidants are usually incorporated to food to prevent development of off-flavour compounds in order to avert oxidative destability of food components [3]. Until recently,

synthetic antioxidants such as butylated hydroxyanisole (BHA), butylated hydroxytoluene (BHT) and tertiary butylhydroquinone (TBHQ) were used to control lipid oxidation in foods. But, present day consumers do not prefer addition of any chemicals in food because of their health risks and toxicity. The fear of adverse effects of incorporating synthetic antioxidants in food products prompted a demand for novel natural antioxidants in food products [4]. A number of studies have been conducted to discover and develop novel antioxidative preservatives with different physicochemical properties needed for diversified food systems [5,6]. A wide variety of herbs, spices and fruits are used more and more as additives with antioxidative capacity $[7,8]$. 
For surimi products, the technique mostly used for obtaining a good gel depends on solubilizing and extracting myofibrillar proteins with 2 to $3 \mathrm{~g} / 100 \mathrm{~g}$ salt and the solubilized expanding proteins form a continuous matrix and then undergo thermal aggregation, cross-linking and develop into fine three dimensional solid-like networks resulting in elastic gel. The cross-linking of myosin promoted by a calcium-dependent endogenous transglutaminase (TGase) contained in fish muscle, which catalyses an acyl transfer reaction between $\gamma$-carboxyamide groups of glutaminyl residues in proteins. Fish with high content of lipid and myoglobin results difficulties in making high quality surimi [9]. To enhance the gel strength of surimi or fish mince, various food-grade ingredients and crosslinking enzymes such as microbial transglutaminase have been used [10]. Due to adverse effects of some ingredients on the surimi gel, particularly on its flavour or colour, the need of natural additives with an ability of protein cross-linking has been paid increasing attention for the surimi industry.

Polyphenolics are one of the compounds that are found in both edible and inedible plants and herbs/spices and it could be the source of a good antioxidant agent. These can act as reducing agents, free radical scavengers and $\mathrm{Fe}^{2+}$ chelators or quenchers in the formation of singlet oxygen $[11,12]$. Thus phenolics are of increasing interest in the food industry because they retard the oxidative degradation of lipids and thereby improve the quality and nutritional value of food [13]. The high antioxidant capacity of these plant parts is particularly due to their content of different phenols, anthocyanins and ascorbic acid, which can act as radical scavengers [14]. The interactions between phenolic compounds and proteins play a very important role in the processing of certain food products. In an alkaline solution phenols may be oxidised easily to their corresponding quinones which can readily undergo attack by nucleophiles such as lysine, methionine, cysteine and tryptophan residues in a protein chain [15]. The formation of rigid molecular structures by reactions of ortho-quinones with proteins has been demonstrated by Strauss \& Gibson [16]. Interactions of different phenolic acids and flavonoids with soy proteins were reported by Rawel et al. [17]. Significant increase in the gel strength of bigeye snapper surimi was found when oxidised phenolic compounds were added [18]. Antioxidant and antimicrobial characteristics of ginger extract have been reported by different workers $[19,20]$.

The in vitro antioxidant activity of gingerol and other constituents of ginger [21] had been reported. Gingerol, the pungent factor in ginger oleoresin, inhibited phospholipids peroxidation induced by the $\mathrm{FeCl}_{3}$ ascorbate system [22]. Inhibition of xanthine oxidase activity responsible for the generation of reactive oxygen species, such as superoxide anion was documented with gingerol [23]. Sekiwa et al. [24] reported that glucosides related to gingerdiol from ginger has antioxidative activity.

The surimi making ability of many freshwater species is relatively low than that of its marine counterpart, but, could be upgraded by manipulating processing techniques. Thai pangas (Pangasianodon hypophthalamus) is extensively cultured in India and Bangladesh. The fish has a great aquaculture potential due to its very high growth rate compared to other popular major carps. The abundant catch of Thai pangas might be utilized as an alternative source of surimi raw material for development of restructured products. This study aims to determine the effects of ginger's (Zingiber officinale) aqueous extract on lipid oxidation and microbial propagation on sausage from Thai pangas surimi during refrigerated storage by evaluating the characteristics such as textural, chemical and microbial besides acceptability.

\section{Materials and Methods}

\section{Preparation of aqueous extract of ginger}

To prepare aqueous extract of locally available ginger (Zingiber officinale), the ginger was peeled, cut into pieces and dried in an hot air oven at temperature $40 \pm 2{ }^{\circ} \mathrm{C}$. It was then ground using an electric blender. Twenty grams of the ground material was soaked in $100 \mathrm{ml}$ of hot sterile water and allowed to stand for $48 \mathrm{~h}$. The crude extracts were obtained by filtration. The process was repeated twice and all the filtrates were collected and subjected to evaporation at $50^{\circ} \mathrm{C}$ in rotary vacuum evaporator (OSAKA J.P. Selecta, Spain). The powdered aqueous extract of ginger was kept in aluminium pouch and stored at -20 ${ }^{\circ} \mathrm{C}$ for future use.

\section{Preparation of surimi}

Fresh pangasius for the study was collected from the local fish farm at Lembucherra, Tripura. Length and weight range of fish were $37-49 \mathrm{~cm}$ and 636-809g respectively. Fishes were washed with chilled water, gutted, dressed, filleted by hand and minced by employing a mechanical meat mincer with a $3 \mathrm{~mm}$ hole plate. Washing of the minced meat was performed in wash tanks maintaining a water temperature of $10{ }^{\circ} \mathrm{C}$ using a fish mince to water ratio of $1: 4(\mathrm{w} / \mathrm{v})$ for three times with ten min duration of each wash (twice with potable water and last one with $0.1 \% \mathrm{NaCl}$ solution to facilitate dewatering). The slurry was stirred for $3 \mathrm{~min}$ and allowed to settle for $2 \mathrm{~min}$ before water was decanted. Final dewatering was carried out using a screw press (Deb Enterprise, India). Sorbitol (4g), sucrose (4g) and polyphosphate $(0.3 \mathrm{~g})$ were added to $100 \mathrm{~g}$ of dewatered mince as cryprotective agents and then mixed for $5 \mathrm{~min}$ in a silent cutter (Sunlabz, India) at a temperature below $10{ }^{\circ} \mathrm{C}$. The washed mince (surimi) was packed in low density polyethylene (LDPE) pouches (500g per pouch) and quickly frozen at $-35{ }^{\circ} \mathrm{C}$ for $2 \mathrm{~h}$ in air blast freezer (Sanyo, Japan) and stored at $-20{ }^{\circ} \mathrm{C}$ in a deep freezer (Vest Frost, Denmark) for development of restructured products within a week.

\section{Preparation of surimi gel}

Frozen surimi was tempered for about $2 \mathrm{~h}$ at $20 \pm 2{ }^{\circ} \mathrm{C}$ until it reached $5 \pm 1{ }^{\circ} \mathrm{C}$, followed by chopping for $1 \mathrm{~min}$ at high speed in a silent cutter (Sunlabz Equipments, Chennai, India). Moisture of surimi was adjusted to $80 \%$ by using ice water. Salt $(\mathrm{NaCl})$ was 
added @2.5\% and mixed in silent cutter for five min followed by microbial transglutaminase (MTGase) @1.0\% and mixed for another five min. Aqueous extract of ginger (GAE) was added to each 500 g part @0.5, 1.0 and 1.5\% and designated as PSgr0.5, PSgr-1.0 and PSgr-1.5 respectively. Throughout the mixing operation temperature of surimi sol was kept below $10^{\circ} \mathrm{C}$. The control (CON) was made without addition of ginger extract. The surimi paste was then stuffed into vinylidene chloride casing $(10 \mathrm{~cm}$ length, $2.0 \mathrm{~cm}$ diameter). Thermal setting was done according to the two-step heating method suggested by Luo et al. [25]. The casings were immersed in water at $40{ }^{\circ} \mathrm{C}$ for $30 \mathrm{~min}$ followed by immersion in water at $85^{\circ} \mathrm{C}$ for $30 \mathrm{~min}$. After cooking, the casings were immediately removed, placed in iced water, and cooled at $4-5^{\circ} \mathrm{C}$ for $30 \mathrm{~min}$. The gels were then stored overnight at $4{ }^{\circ} \mathrm{C}$ in a refrigerator. For storage study, the gels were stored at $4{ }^{\circ} \mathrm{C}$ in a refrigerator for 20 days and storage changes were analysed at 4 days interval.

\section{Moisture, ash, protein, fat content and $\mathbf{p H}$}

Moisture, ash, protein and fat content of pangasius surimi were determined according to AOAC [26]. For determination of the $\mathrm{pH}, 10 \mathrm{~g}$ of sample were homogenized with $50 \mathrm{ml}$ distilled water and $\mathrm{pH}$ value was measured by a digital pH-meter (Sartorius, PB-20).

\section{Determination of protein solubility, WHC}

Gel $(0.5 \mathrm{~g})$ were homogenised in $10 \mathrm{ml}$ of $0.6 \mathrm{M} \mathrm{KCl}$ in $50 \mathrm{mM}$ $\mathrm{pH} 7.4$ tris- $\mathrm{HCl}$ buffer for $1 \mathrm{~min}$ in a tissue homogenizer (IKA, Germany). The homogenate was centrifuged at 10,000 rpm for $10 \mathrm{~min}$ at $4{ }^{\circ} \mathrm{C}$ (Remi, India). The supernatant was diluted tenfold with $0.6 \mathrm{M} \mathrm{KCl}$ and protein determination was performed Biuret method [27]. Analyses were performed in triplicate and the solubility was expressed in mg of soluble protein/100mg of gel.

WHC was evaluated by the technique outlined by Barrera et al. [28]. A portion of $5 \mathrm{~g}$ of each gel was weighed and placed on 8 layers of filter paper (Whatman No. 1). Samples were placed in $50 \mathrm{~mL}$ centrifuge tubes and centrifuged at $5000 \mathrm{xg}$ at $4{ }^{\circ} \mathrm{C}$ for $15 \mathrm{~min}$ (make REMI, India). Immediately after centrifugation, the gels were removed and re-weighed. WHC was expressed as the weight of the centrifuged gels relative to the original weight of samples.

WHC $(\%)=(\mathrm{W} 2 / \mathrm{W} 1) \times 100$

where W1 represents the weight of the gel before centrifugation and W2 represents the weight of the gel after centrifugation.

\section{Determination thiobarbituric acid reactive substances (TBARS)}

The 2-thiobarbituric acid (TBA) assay was carried out according to the procedure of Schmedes \& Holmer [29]. Sausage sample $(10 \mathrm{~g})$ was mixed with $25 \mathrm{ml}$ of trichloroacetic acid solution (200g/l of TCA in $135 \mathrm{ml} / \mathrm{l}$ phosphoric acid solution) and homogenized in a blender for 30s. After filtration, $2 \mathrm{ml}$ of the filtrate were added to $2 \mathrm{ml}$ TBA solution ( $3 \mathrm{~g} / \mathrm{l})$ in a test tube. The test tubes were incubated at room temperature in the dark for $20 \mathrm{~h}$; then the absorbance was measured at $532 \mathrm{~nm}$ by using UVVIS spectrophotometer (model UV-1200, Shimadzu, Japan). TBA value was expressed as mg malonaldehyde per $\mathrm{kg}$ of sausage. The values of three independent experiments were recorded as mean \pm SD.

\section{Determination of protein carbonyls}

Protein carbonyls were estimated according to the method suggested by Levine et al. [30]. Surimi gel $(0.5 \mathrm{~g})$ was homogenised in $10 \mathrm{ml} 50 \mathrm{~mm}$ tris-buffer (pH: 7.4 ) containing $1 \mathrm{mM}$ EDTA and $0.01 \%$ BHT. $200 \mu$ l of the homogenate was precipitated with $50 \mu \mathrm{l}$ of TCA $(100 \%)$ followed by centrifugation $(10,000 \mathrm{xg})$ for $5 \mathrm{~min}$ and the pellet was incubated in the dark for $1 \mathrm{~h}$ with $500 \mu \mathrm{l}$ of $10 \mathrm{~mm}$ dinitrophenylhydrazine (DNPH) in $2 \mathrm{M} \mathrm{HCl}$. A blank without added DNPH was made in $2 \mathrm{M} \mathrm{HCl}$ and incubated in similar way. The samples were precipitated with $50 \mu \mathrm{l}$ TCA $(100 \%)$ and centrifuged $(10,000 \mathrm{xg})$ for $5 \mathrm{~min}$ followed by washing of the pellets three times with $1 \mathrm{ml}$ ethanol/ethyl acetate $1: 1(\mathrm{v} / \mathrm{v})$. The pellet was re-dissolved in $1 \mathrm{ml}$ of $6 \mathrm{M}$ guanidine chloride in $20 \mathrm{~mm} \mathrm{KH2PO4.} \mathrm{Carbonyl} \mathrm{content} \mathrm{was} \mathrm{calculated}$ using the molar absorption coefficient of $22,000 \mathrm{M}-1 \mathrm{~cm}-1$ relative to protein concentration and results were expressed in nmoles carbonyl per mg of protein.

\section{Determination of whiteness}

Colour of gel was determined in triplicate using spectrocolourimeter (Colourflex EZ, Hunter Associates Laboratory, Inc, Reston, VA) with illuminant of D $65 / 10^{\circ}$. This instrument was calibrated with black and white reference tiles before analysis. A horizontal section of gel measuring approx. $5 \mathrm{~mm}$ was placed above the light sources and post processing $\mathrm{L}^{*}$ lightness), a* (redness/greenness) and b* (yellowness/blueness) values were recorded. The CIELAB $\left(\mathrm{L}^{*}, \mathrm{a}^{*}, \mathrm{~b}^{*}\right)$ colour scale was used for the study. Whiteness was calculated as described by Lanier et al. (1991) as follows:

$$
\text { Whiteness }=100-\left(100-L^{*}\right)+a^{*} 2+b^{*} 2 \frac{1}{2}
$$

\section{Texture profile analysis (TPA)}

Texture profiles of gel were determined using a TA-XT2 Stable Micro Systems Texturometer (Surrey, England, UK). Restructured fish products (surimi gel) were removed from the casings and equilibrated to room temperature for $30 \mathrm{~min}$ in a plastic bag to avoid dehydration before the mechanical properties were measured. Textural profile analysis (TPA) was performed using an aluminium cylindrical probe $(\mathrm{P} / 50)$ with $50 \mathrm{~mm}$ diameter. Samples were compressed to $60 \%$ of the initial height using a compression speed of $60 \mathrm{~mm} \mathrm{~min}^{-1}$. Hardness, springiness, cohesiveness and gumminess were reported for each treatment. Six samples were analysed for each treatment at room temperature $\left(25-27^{\circ} \mathrm{C}\right)$. 


\section{SDS-polyacrylamide gel electrophoresis}

Gel electrophoresis was carried out according to the method of Laemmli [31] using $10 \mathrm{~g} / 100 \mathrm{ml}$, acrylamide separating gel and $4 \mathrm{~g} / 100 \mathrm{ml}$ stacking gel. About $3 \mathrm{~g}$ sample in $27 \mathrm{ml}$ of $20 \mathrm{mmol} / \mathrm{l}$ Tris-HCl buffer (pH 8.0) containing $10 \mathrm{~g} / 100 \mathrm{~mL}$ SDS was homogenized at $10,000 \mathrm{r} / \mathrm{min}$ for $30 \mathrm{~s}$, and then incubated at $85{ }^{\circ} \mathrm{C}$ for $30 \mathrm{~min}$. The mixture was centrifuged at $10,000 \mathrm{xg}$ for $5 \mathrm{~min}$ to remove un dissolved pieces after vigorous agitation using a vortex mixer (Remi, India). An aliquot taken from the middle layer of the supernatant was heated at $100{ }^{\circ} \mathrm{C}$ for $5 \mathrm{~min}$ in Tris-glycine buffer ( $\mathrm{pH}$ 8.8) containing $1 \mathrm{~g} / 100 \mathrm{ml}$ SDS and 1 $\mathrm{ml} / 100 \mathrm{ml} \mathrm{L}$-mercaptoethanol. Electrophoresis (Bio-RAD Mini Protein System, USA) was carried out at a constant voltage of $95 \mathrm{~V}$ using an electrophoretic buffer of Tris-glycine containing $0.1 \mathrm{~g} / 100 \mathrm{ml}$ SDS.

\section{Sensory evaluation}

Sensory evaluation was performed by a panel of 6 judges. The panel evaluated each treatment within each replication in triplicate, and the evaluation was performed with the samples at room temperature. The panel judges were trained on the attributes of the sausage type products such as colour, flavour, taste and texture. Based on those attributes they were instructed to evaluate acceptability using ten-point Hedonic Scale (like extremely-9, like very much-8, like moderately-7, like slightly-6, neither like nor dislike-5, dislike slightly-4, dislike very much3 , dislike moderately-2, dislike slightly-1). A score below 6 was considered as rejected.

\section{Statistical analysis}

The data obtained were analyzed using analysis of variance (ANOVA), and when significant differences were found, comparisons among means were carried out by using Duncan's Multiple Comparison Test $(\mathrm{p}<0.05)$ by Statistical Package for Social Sciences (SPSS, version 11.0 for windows).

\section{Results and Discussion}

\section{Proximate analyses of fish muscle and surimi}

The principal biochemical constituents of raw material fish Pangasius (Pangasianodon hypophthalmus) were moisture $\left(740.4 \pm 2.5 \mathrm{~g} \mathrm{~kg}^{-1}\right)$, protein $\left(163.9 \pm 3.4 \mathrm{~g} \mathrm{~kg}^{-1}\right)$, fat $\left(75.7 \pm 1.4 \mathrm{~g} \mathrm{~kg}^{-1}\right)$ and ash $\left(10.9 \pm 0.2 \mathrm{~g} \mathrm{~kg}^{-1}\right)$. The proximate analysis showed that the fish had low moisture and high protein and moderate fat content. Lower moisture and higher lipid content in pangas muscle was also reported by Hossain et al. [32]. Silverstein et al. [33] reported the proximate composition of channel catfish as moisture (74$76 \%)$, protein $(17-19 \%)$ and fat (3-6.9\%). Whereas, in another study, proximate composition of catfish (Clarias gariepinus) was reported moisture, protein and fat content as $71.85 \%$, $19.51 \%$ and $14.28 \%$ respectively [34]. There are influences of various factors such as nutrition, living area, and fish size, catching season, seasonal and sexual variation as well as other environmental condition on the proximate composition of fish species [35]. The surimi had moisture $\left(795.7 \pm 1.8 \mathrm{~g} \mathrm{~kg}^{-1}\right)$, protein $\left(146.8 \pm 2.7 \mathrm{~g} \mathrm{~kg}^{-1}\right)$, fat $\left(13.3 \pm 0.4 \mathrm{~g} \mathrm{~kg}^{-1}\right)$ and ash $\left(33.6 \pm 1.4 \mathrm{~g} \mathrm{~kg}^{-1}\right)$. Washing reduced total protein content which may be explained as the removal of sarcoplasmic protein during washing which makes up to $20 \%$ to $25 \%$ of total protein of fish muscles $[36,37]$. Majumdar et al. [38] also reported a significant decrease of protein content after washing of silver carp mince. Removal of sarcoplasmic proteins may result increased concentration of myofibrillar proteins followed by improved water holding capacity of meat, because of increased hydration of protein due to removal of blood, pigments, proteins etc. during washing [39].

\section{Changes in biochemical properties during refrigerated storage}

Changes in $\mathbf{p H}, \mathrm{WHC}$ and protein solubility: Changes in $\mathrm{pH}$, water holding capacity (WHC) and protein solubility (PS) during refrigerated storage are given in Figure 1 . The initial $\mathrm{pH}$ value (Figure 1a) ranged from 7.65 (in control sample) to 7.277.42 (in treated samples). Significant $(\mathrm{p}<0.05)$ reduction of $\mathrm{pH}$ in GAE treated samples may be attributed to the interaction of organosulphur/phenolic compounds of ginger with fish muscle proteins. In all GAE added formulations, storage had a significant $(p<0.05)$ effect on the $\mathrm{pH}$ values, which tended to increase with storage time.

Indices such as water holding capacity (Figure 1b), is often used to assess the textural quality of the restructured fish products and it also indicates the deterioration of protein quality during low temperature storage. Water holding capacity increased $(p<0.05)$ proportionately with the addition of GAE. The increases in WHC in day- 1 in treated sausages may be explained as the formation of stronger network induced by GAE might imbibed more water. However, the variation in WHC between the treatments may be due to differences in the concentration of phenolics in different treatments. From day- 1 onwards, the differences between the treatments were significant $(p<0.05)$. This may be explained as the result of protein denaturation induced by refrigerated storage leading to low affinity for water and it was accompanied by gradual loss of protein solubility. Moreover, modification of protein-phenolics interaction with the gradual denaturation and/or degradation of protein during storage may also be responsible for changes in WHC of protein as observed in this study. The texture of gel is also dependent on WHC which affect or influence sensory acceptability. So WHC is important to maintain at higher level during the storage period for better sensory quality.

The decrease in solubility (Figure 1c) suggests the formation of protein aggregates during gelation process. During heating, proteins underwent denaturation and aggregation to form a three dimensional structure. The alteration of protein extractability is a useful factor which may be used to determine the textural quality of fish muscle, as protein aggregation is accompanied by a significant decrease in their solubility [40]. In the present study, protein solubility not changed in Day-1, but as the storage progressed the PS values were found to be decreased significantly $(\mathrm{P}<0.05)$ in all the groups indicating the formation of protein 
aggregates. The formation of disulphide bond which results in the aggregation of proteins [41] might have contributed to low solubility of proteins. Hydrogen bonds might involve in the interactions between hydroxyl groups of phenolic compounds and the nitrogen or oxygen of amino acids. From the result, the decreased protein solubility over the storage period indicated the aggregation as well as denaturation of proteins caused by low temperature.

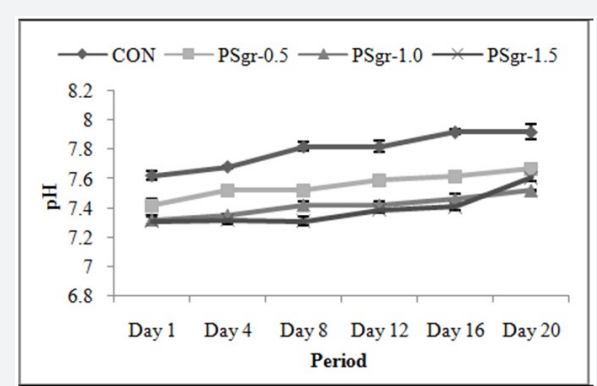

(a)

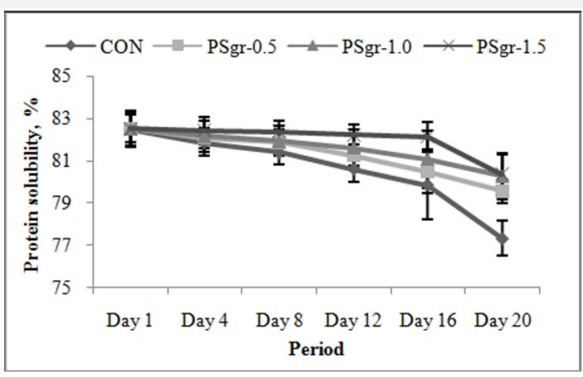

(C)

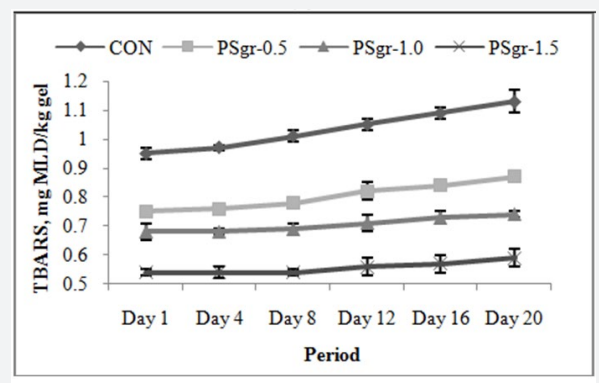

(e)

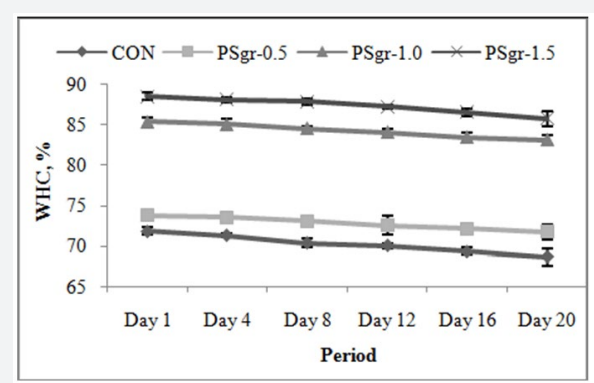

(b)

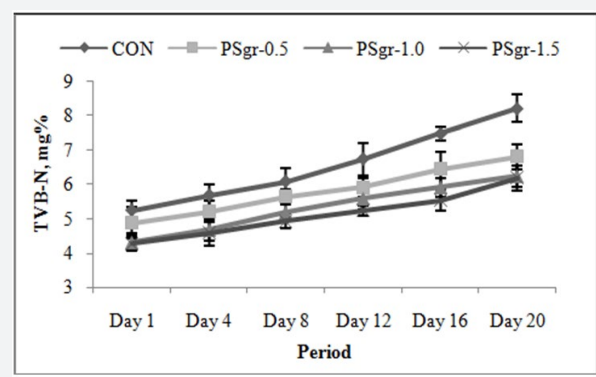

(d)

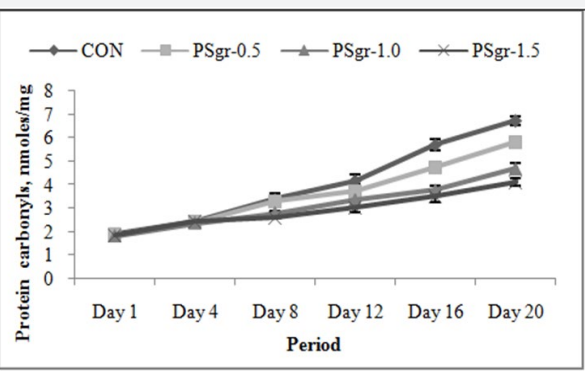

(f)

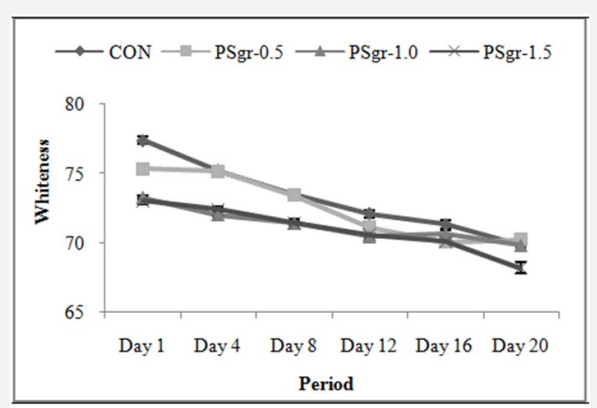

(g)

Figure 1: Changes of quality and whiteness during refrigerated storage of ginger's (Zingiber officinale) aqueous extract incorporated transglutaminase mediated sausages from Pangasius surimi: (a) pH, (b) WHC, (c) Protein solubility, (d) TVB-N, (e) TBARS, (f) Protein carbonyls, and $(\mathrm{g})$ whiteness.

$\mathrm{CON}=$ surimi with MTGase (1.0\%) and without ginger extract, PSgr-0.5, PSgr-1.0 and PSgr-1.5 are MTGase (1.0\%) mediated gel with 0.5, 1.0 and 1.5 percent ginger aqueous extract respectively.

Error bars indicate standard deviation of 3 determinations.

Changes in total volatile basic nitrogen (TVB-N) and thiobarbituric acid reactive substances (TBARS)

Changes in TVB-N in GAE treatment as well as during storage period of surimi gel are presented in Figure 1d. Although, increase of TVB-N values in GAE treated samples compared to control in Day-1 was not significant ( $p>0.05$ ), but changes during storage 
period was significant $(\mathrm{p}<0.05)$ and also proportionate with the GAE. Figure 1e depicts the effect of different concentrations of GAE on TBARS value of surimi sausage during refrigerated storage. TBARS values increased $(\mathrm{p}<0.05)$ in treated samples compared to control in Day-1, but increase was proportionate with GAE. There was no significant ( $p>0.05$ ) differences in TBARS value in Day-1 and Day-4 between the control and GAE treated groups. As the storage time increased, there was significant $(\mathrm{p}<0.05)$ differences in TBARS value between GAE added samples and control. Although, with the progress of storage period, the TBARS value increased in all the treatments, but the rate of increase varied, depending upon the concentration of GAE. At the end of the storage period, the increase of TBARS value from the initial value was in the order of $\mathrm{CON}>\mathrm{PSgl}-0.5>\mathrm{PSgl}-1.0>\mathrm{PSgl}-$ 1.5. Lipid oxidation occurred during refrigerated storage might cause the denaturation of proteins. Many lipid degradation products are also capable of cross-linking polypeptides and thus are responsible for the generation of insoluble protein aggregate. This possibly resulted in the loss in solubility of protein, especially when the storage time increased. Aldehydes formed during lipid oxidation can interact with amino groups of protein to form Schiff base products [42].

Lipid oxidation represented by TBARS was reduced with the higher concentrations of GAE. This result was in accordance with that of Yang et al. [43], who noted that the antioxidant activity of several compounds of plant extracts was concentration dependent. The investigated lipid oxidation preventive activity of the five different treatments followed the order PSgl-1.5 $>$ PSgl-1.0 >PSgl-0.5 >CON. Our results, therefore, indicate that GAE could slow down the increase in TBARS values, implying a retardation of lipid oxidation in GAE treated samples. This retardation may be due to the presence of polyphenol compounds (such as 6-gingerol and its derivatives) in the GAE [44]. Those compounds are known to be effective in preventing lipid oxidation [45]. Shogaol and gingerone found in ginger reported to have strong antioxidant activities. Ginger extract was reported to be effective in retarding the development of rancidity in salted pork patties and its effectiveness was directly related to the concentration.

\section{Changes in carbonyl compounds}

Recently the impact of protein oxidation on protein functionality and muscle food quality has received more attention [46]. In oxidising environments proteins are very susceptible to chemical modification, such as amino acid destruction, peptide scission and formation of protein-lipid complexes [47]. There is also possibility that lipid oxidized products such as radicals and hydroperoxides react with protein leading to the loss of protein functionality.

Estimation of carbonyl compounds indicates most important changes taking place during the oxidation of proteins. Carbonyl compounds are usually formed by major amino acids, such as lysine, histidine, proline and arginine yield and therefore the measuring concentration of such compounds is a meaningful indicator of the oxidative status of muscle proteins [48]. Changes in the protein carbonyls of different treatments during refrigerated storage are shown in Fig. 1f. There was no significant difference between treatment and control in Day-1. As storage progressed protein oxidation was evident by a significant $(\mathrm{P}<0.05)$ increase in the protein carbonyl content. But the treated gel showed significant difference $(\mathrm{P}<0.05)$ with control in all sampling days. At the end of the storage period, control showed the highest and the surimi gel with 1.5\% GAE showed lowest levels of carbonyl content. The order of protection offered against the formation of carbonyl compounds was PSgl-1.5> PSgl-1.0> PSgl-0.g> control. These results are consistent with lipid oxidation products emphasizing a possible relationship between the protein carbonyl formation and lipid peroxidation (Figure 1f).

The lowest carbonyl contents in GAE treated restructured products suggests a protective role of this extract against oxidation of proteins. Certain phenolic acids have been reported to inhibit formation of protein carbonyls in meat products as measured by DNPH method [49]. Likewise, in our study also the phenolic rich extracts of ginger prevented the formation of protein carbonyls and thereby protein oxidation. Phenolic compounds have been suggested to inhibit the oxidation of proteins either by retarding the lipid oxidative reactions or by binding to the proteins or by forming complex with them [50].

\section{Changes in whiteness}

Whiteness of the gels was found to be reduced $(\mathrm{P}<0.05)$ upon addition of GAE (Figure 1g). That may be due to moderately grayish colour of GAE. This may be due to interaction of ginger's organosulphur compounds with the muscle pigments leading to increase of the whiteness of the gel. But there were no significant changes $(\mathrm{P}>0.05)$ in whiteness during refrigerated storage of all the treatments as well as control except treatment with higher percent of GAE (PSgr1.5). The differences in colour alteration between treatments were possibly caused by the differences in pigment content in muscle. The result also indicates that the surimi treated with GAE prevented the oxidation of heme proteins present in the gel which are red in their reduced form and brown in their oxidized ferric form leading to maintain the whiteness during storage.

\section{Changes in texture profiles}

Amongst the textural attributes; hardness, springiness, cohesiveness and gumminess were measured periodically and presented in Figure 2. Hardness, springiness and gumminess of sausage were affected most due to addition of GAE. Hardness, peak force required for the first compression, increased $(\mathrm{P}<0.05)$ with increase of GAE up to $1.0 \%$, but decreased thereafter in sausage having $1.5 \%$ GAE. Maximum hardness was found in sausage containing $1.0 \%$ GAE. This may be explained that more cross links following more GAE might reduce the flexibility of protein aggregates. The decreased gel strength at higher concentrations $(1.5 \%)$ of GAE in the present study might be 
associated with self-aggregation of phenolic compounds, leading to the loss in capability of protein cross-linking. Cao et al. [51] reported the polymerisation of protein molecules as a possible subsequent reaction of different proteins with phenolic substances. This study also supports the observation by Ngapo et al. 1996 i.e., more interactions or cross links restrict the flexibility of the protein aggregates, and the gels become less springy and more rigid. The lower solubility of large phenolic compounds at high concentration causes the difficulty to interact with proteins [52]. It is also possible that the size of the phenolic compound can decrease its conformational flexibility in proteinphenolic compound interactions.

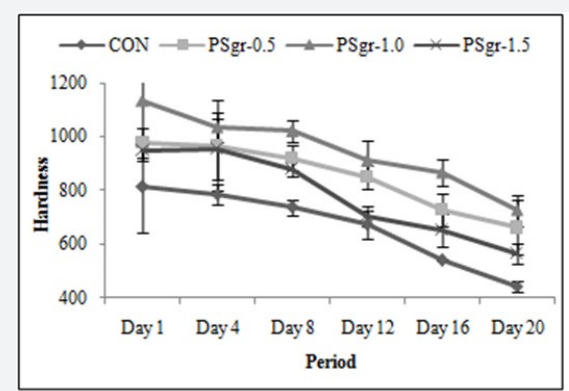

(a)

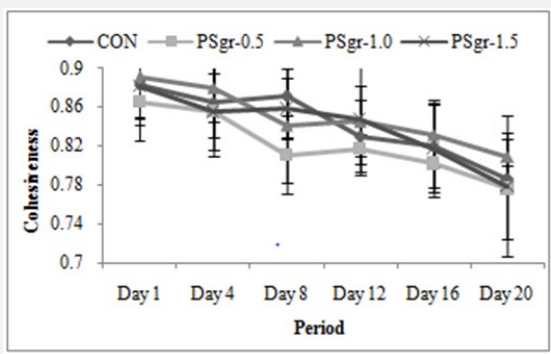

(C)

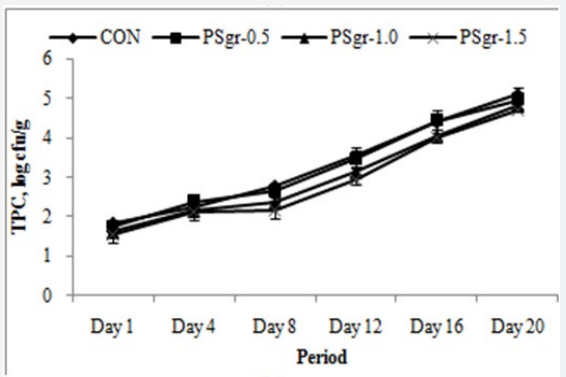

(e)

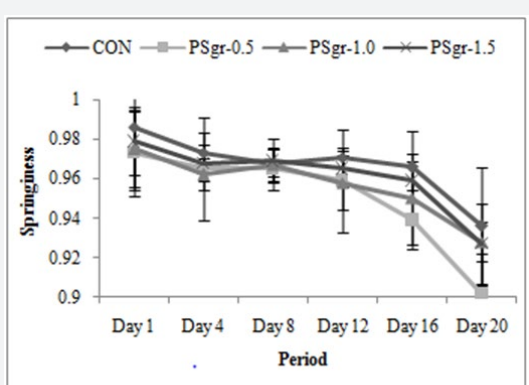

(b)

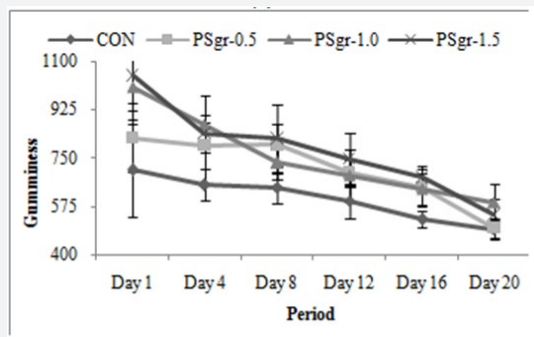

(d)

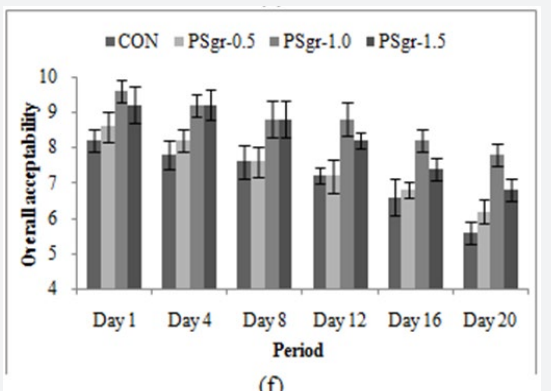

(f)

Figure 2: Changes in texture, TPC and overall acceptability during refrigerated storage of ginger's (Zingiber officinale) aqueous extract incorporated transglutaminase mediated sausages from Pangasius surimi: (a) hardness, (b) springiness, (c) cohesiveness, (d) gumminess, (e) TPC, and (f) overall acceptability

CON = surimi with MTGase (1.0\%) and without ginger extract, PSgr-0.5, PSgr-1.0 and PSgr-1.5 are MTGase (1.0\%) mediated gel with 0.5 , 1.0 and 1.5 percent ginger aqueous extract respectively.

Error bars indicate standard deviation of 6 determinations.

As the storage period increased, the hardness decreased with varying rate. On Day-20, the hardness of the sausages was found to be in the order of PSgl-1.0>PSgl-0.5>PSgl-1.5 > CON. Such behaviour of gels may be because of protein denaturation during low temperature storage and this was also found to be associated with decrease of WHC and protein solubility. Gumminess and springiness decreased $(\mathrm{P}<0.05)$ during the refrigerated storage of surimi gels, whereas no significant $(\mathrm{P}>0.05)$ change was observed in case of cohesiveness. Such changes of texture profile was presumed to be due to the increased denaturation of proteins, induced by extended refrigerated storage accompanied by loss of WHC and protein solubility.

\section{Changes in TPC}

Total plate count increased in all the groups during the period of refrigerated storage, but difference between control and GAE treated RPs was not significant upto day-4 (Figure1d). There were no significant differences $(\mathrm{P}>0.05)$ with respect to TPC between the samples and ranged from 1.73 to $1.85 \log$ $\mathrm{cfu} / \mathrm{g}$. Whereas, on 20th day, the TPC of control increased to $5.09 \log \mathrm{cfu} / \mathrm{g}$ which significantly $(\mathrm{P}<0.05)$ differed from the treated groups, wherein the count ranged from 4.49 to $4.97 \mathrm{log}$ $\mathrm{cfu} / \mathrm{g}$ with lowest recorded from sample treated with $2 \%$ GAE. Although the antimicrobial activity of ginger and ginger derived 
organosulfur compounds were reported in culture media, few reports are available on its effect in meat products. Whereas, the antimicrobial activity of organosulfur compounds was widely investigated against both food spoilage bacteria and food-borne pathogens [53].

\section{Acceptability}

The acceptability scores of the samples were assigned based on the attributes such as appearance, flavour, taste and texture. The acceptability of the product over the storage time as affected by different concentration of ginger's aqueous extract is presented in Figure 2. The trend of overall acceptability observed in the day-1 was maintained even on day-20. All the treated groups were acceptable up to the end of the storage, however, they were scored in the order of PSgl-1.0 > PSgl-1.5 > PSgl-0.5. The control was found acceptable only up to Day-16 and sample PSgl-0.5 and PSgl-1.5 scored between slightly liked and moderate at the end of storage period. The consumers' acceptability is usually based on the cumulative effect of all the sensory qualities, viz., appearance, texture, flavour, taste etc. Textural properties of sausage type of products are regarded as an important criterion for the consumer's acceptability is concerned. In this study, the hardness of treatment PSgl-1.0 estimated to be highest amongst the samples. Next to texture, the sensory attribute which attracts the consumer more is flavour. Ginger has got some pungency in its flavour and too much ginger flavour is not accepted by the consumers. The result indicated that minimum ginger flavour in treatment with $1.0 \%$ GAE was highly accepted compared to others.

\section{Effect of GAE on protein patterns}

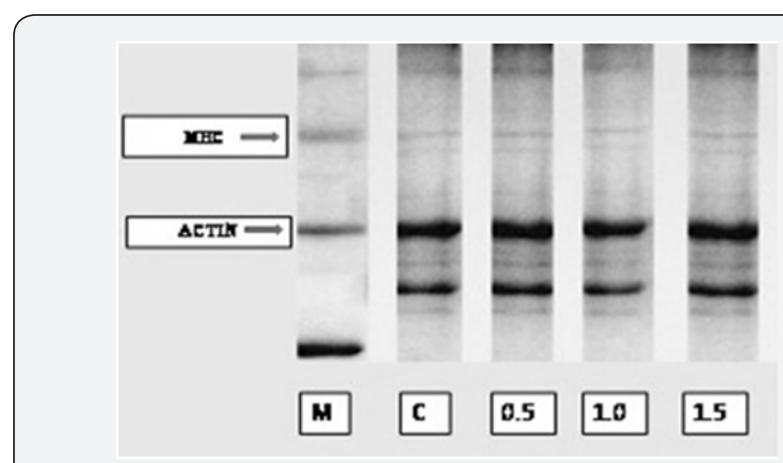

Figure 3: Protein patterns of GAE treated surimi gel in day- $1^{*}$. ${ }^{*} \mathrm{M}=$ Protein ladder, $\mathrm{C}=$ surimi without ginger extract, $0.5,1.0$ and 1.5 are surimi gel with $0.5,1.0$ and 1.5 percent ginger's aqueous extract respectively.

Protein patterns of gel in control and GAE treated groups in day-1 is depicted in Figure 3. The thickness of the myofibrillar head chain (MHC) was found to be more in treated samples and also tended to increase with increasing concentration of GAE. Act in was found to be the dominant protein in the gel, suggesting that act in was more resistant to proteolysis or could not be polymerised during gelation. The result was in agreement with Benjakul et al. [54] who reported that act in Pacific whiting muscle was more resistant to proteolysis than MHC. The result suggests that GAE might be able to inhibit the degradation of MHC to some extent, as evidenced by the more retained MHC in treated gels. Protein cross-links might be more resistant to proteolysis caused by indigenous proteases. Phenolics present in GAE might have exerted some protective activity against certain proteases. Kroll et al. [55] reported that the interactions between phenolic compounds and proteins may result in inhibiting certain proteases $[56,57]$.

\section{Conclusion}

The study revealed that addition of ginger's aqueous extract in surimi sausage reduced lipid and protein oxidation during refrigerated storage. Moreover, the textural quality of the surimi sausage also improved with incorporation of ginger's aqueous extract. Therefore, for development of sausages from freshwater fish like pangasius with inherent low gelling capacity, ginger in the form of aqueous extract may be used for safety of the product as well as for making the product as health food due to its enrichment with antioxidants from ginger.

\section{Acknowledgement}

Authors thank Department of Biotechnology, Govt. of India, New Delhi for funding project (Grant No. BT/379/NE/ TBP/2012 Dated, November 30, 2012) under which this work was undertaken. The assistances rendered by the technical staff of the Department of Fish Processing Technology is sincerely acknowledged.

\section{References}

1. Uchid K, Stadtman ER (1993) Covalent modification of 4-hydroxynoneal to glyceraldehydes-3-phosphate. J Biol Chem 268(9): 335-343.

2. Buttkus H (1966) Preparation and properties of trout myosin. J Fish Res Board Can 23(4): 563-573.

3. Yu L, Scanlin L, Wilson J, Schmidt G (2002) Rosemary extracts as inhibitors of lipid oxidation and color change in cooked turkey products during refrigerated storage. Food Science 67(2): 582-585.

4. Aligiannis N, Mitaku S, Tsitsa-Tsardis E, Harvala C, Tsaknis I, et al. (2003) Methanolic extract of Verhascum macrurum as a source of natural preservative against oxidative rancidity. J Agric Food Chem 51: 7308-7312.

5. Athukorala Y, Lee K, Shahidi F, Heu MS, Kim H, et al. (2003) Antioxidant efficacy of extracts of an edible red algae (Grateloupia filicina) in linoleic acid and fish oil. J Food Lipids 10(4): 313-327.

6. Rey AI, Hopia A, Kivikari R, Kahkonen M (2005) Use of natural food/ plant extracts: cloudberry (Ruhus chamaemorus), beetroot (Beta vulgaris "Vulgaris") or willow herb (Epilohium angustifolium) to reduce lipid oxidation of cooked pork patties. LWT Food Sci Technol 38(4): 363-370.

7. Brannan RG, Mah E (2007) Grape seed extract inhibits lipid oxidation in muscle from different species during refrigerated and frozen storage and oxidation catalyzed by peroxynitrite and iron/ascorbate in a pyrogallol red model system. Meat Sci 77(4): 540-546.

8. Haak L, Raes K, Smet SD (2009) Effect of plant phenolics, tocopherol and ascorbic acid on oxidative stability of pork patties. J Sci Food Agric 89(8): 1360-1365.

9. Chen HH (2002) Decoloration and gel-forming ability of horse mackerel mince by air-flotation washing. J Food Sci 67(8): 2970-2975. 
10. Benjakul LS, Visessanguan W, Chantarasuwan C (2004) Cross-linking activity of sarcoplasmic fraction from bigeye snapper (Priacanthus tayenus) muscle. LWT- Food Sci Technol 37: 79-85.

11. Juntachote T, Berghofer E, Bauer F, Siebenhandl S (2006) The application of response surface methodology to the production of phenolic extracts of lemon grass, galangal, holy basil and rosemary. Int J Food Sci Technol 41(2): 121-133.

12. Pizzale L, Bortolomeazzi R, Vichi S, Uberegger E, Conte LS (2002) Antioxidant activity of sage (Salvia officinalis and S. fructicosa) and oregano (Origanum onites and 0 . indercedens) extracts related to their phenolic compound content. J Agri Food Chem 82(14): 1645-1651.

13. Wojdylo A, Oszmianski J, Czemerys R (2007) Antioxidant activity and phenolic compounds in 32 selected herbs. Food Chem 105(3): 940-949.

14. Pantelidis GE, Vasilakakis M, Manganaris GA, Diamantidis GR (2007) Antioxidant capacity, phenol, anthocyanin, and ascorbic acid contents in raspberries, blackberries, red currants, gooseberries and Cornelian cherries. Food Chem 102(3): 777-783.

15. Hurrell RF, Finot PA (1984) Nutritional consequences of the reactions between proteins and oxidised polyphenolic acids. Adv Exptl Med Biol 177: 423-435.

16. Strauss G, Gibson SM (2004) Plant phenolics as cross-linkers of gelatin gels and gelatin-based coacervates for use as food ingredients. Food Hydrocol 18(2004): 81-89.

17. Rawel HM, Czajka D, Rohn S, Kroll J (2002) Interactions of different phenolic acids and flavonoids with soy proteins. Int J Biol Macromol $30(3-4): 137-150$.

18. Balange A, Benjakul S (2009) Enhancement of gel strength of bigeye snapper (Priacanthus tayenus) surimi using oxidised phenolic compounds. Food Chem 113: 61-70.

19. Lee YB, Kim YS, Ashmore CR (1986) Antioxidant property in ginger rhizome and its application to meat products. J of Food Sci 51(1): 2023.

20. Mendiratta SK, Anjaneyulu ASR, Lakshmanan V, Naveena BM, Bisht GS (2000) Tenderizing and antioxidant effect of ginger extract on sheep meat. J Food Sci Technol 37: 565-570.

21. Kikuzaki H, Nakatini N (1993) Antioxidant effect of some ginger constituents. Journal of Food Sci 58(6): 1407-1410.

22. Aeschbach R, Loliger J, Scott BC, Murcia A, Butler J, et al. (1994) Antioxidant actions of thymol, carvacrol, 6-gingerol, zingerone and hydroxytyrosol. Food Chem Toxicol 32(1): 31-36.

23. Chang Y, Cesarman E, Pessin MS, Lee F, Culpepper J, et al. (1994) Identification of herpesvirus-like DNA sequences in AIDS-associated Kaposi's sarcoma. Science 266(5192): 1865-1869.

24. Sekiwa Y, Kubota K, Kobayashi A (2000) Isolation of novel glucosides related to gingerdiol from ginger and their antioxidative activities. J Agric Food Chem 48(2): 373-377.

25. Luo YK, Shen HX, Pan DD, Bu GH (2008) Gel properties of surimi from silver carp (Hypophthalmichthys molitrix) as affected by heat treatment and soy protein isolate. Food Hydrocol 22(8): 1513-1519.

26. AOAC (2005) Official Methods of Analysis. (16 $6^{\text {th }}$ edn), Association of Official Analytical Chemists, Washington, USA.

27. Gornall AG, Bardawill CJ, David MM (1949) Determination of serum proteins by means of the biuret reaction. J Biol Chem 177: 751-766.

28. Barrera AM, Ramirez JA, Gonzalez-Cabriales JJ, Vazquez M (2002) Effect of pectins on the gelling properties of surimi from silver carp. Food Hydrocol 16: 441-447.

29. Schmedes A, Holmer G (1989) A new thiobarbituric acid (TBA) method for determination of free malonaldehyde (MDA) and hydroperoxides selectivity as a measure of lipid peroxidation. J Am Oil Chem Soc 66: 813-817.

30. Levine RL, Williams JA, Stadtman ER, Shacter E (1994) Carbonyl assays for determination of oxidatively modified proteins. Methods Enzymol 233: 346-357.

31. Laemmli UK (1970) Cleavage of structural proteins during the assembly of the head of bacteriophage T4. Nature 227(5259): 680-685.

32. Hossain MI, Kamal MM, Shikha FH, Hoque MS (2004) Effect of washing and salt concentration on the gel forming ability of two tropical fish species. Int J Agril Biol 6(5): 762-766.

33. Silverstein JT, Wolters WR, Shimizu M, Dickhoff WW (2000) Bovine growth hormone treatment of channel catfish: strain and temperature effects on growth, plasma IGF-I levels, feed intake and efficiency and body composition. Aquacult 160: 77-88.

34. Chukwu O, Shaba IM (2009) Effects of drying methods on proximate compositions of catfish (Clarias gariepinus). World J Agri Sci 5(1): 114 116.

35. Sankar TV, Ramachandran A (2001) Changes in biochemical composition in Indian Major Carp in relation to size. Fish Technol 38(1): 22-27.

36. Negbenebor CA, Godiya AA, Igene JO (1999) Evaluation of Clarias anguillaris treated with spice (Piper guineense) for washed mince and kamaboko-type products. J Food Comp Analy 12: 315-322.

37. Taskaya L, Cakli S, Kisla D, Kilinc B (2003) Quality changes of fish burger from rainbow trout during refrigerated storage. J Fish Aqua Sci 20: $147-154$.

38. Majumdar RK, Deb S, Dhar B, Priyadarshini BM (2012) Chemical changes in washed mince of silver carp (Hypophthalmichthys molitrix) during frozen storage at $-20^{\circ} \mathrm{C}$ with or without cryoprotectants. J Food Proc Preserv.

39. Lin T, Park J (1997) Effective washing conditions reduce water usage for surimi processing. J Aqua Food Prod Technol 6(2): 65-79.

40. Badii F, Howell NK (2002) Effect of antioxidants, citrate, and cryoprotectants on protein denaturation and texture of frozen cod (Gadus morhua). J Agri Food Chem 50(7): 2053-2061.

41. Lim HK, Haard NF (1984) Protein insolubilization in frozen Greenland halibut (Reinhardtius hippoglossoides). J Food Biochem 8(3): 163-187.

42. Zamora R, Alaiz M, Hidalgo FJ (1999) Modification of histidine residues by 4, 5- epoxy-3-alkenals. Chem Res Toxicol 12(7): 654-660.

43. Yang GC, Yasaei PM, Page SW (1993) Garlic as antioxidant and free radical scavengers. J Food Drug Analy 1: 357-364.

44. Govindarajan VS (1982) Ginger-chemistry, technology, and quality evaluation: Part 2. CRC Crit. Rev Food Sci Nutri 17(3): 189-258.

45. Stoilova I, Krastanov A, Stoyanova A, Denev P, Gargova S (2007) Antioxidant activity of a ginger extract (Zingiber officinale). Food Chem 102(3): 764-770.

46. Baron CP, Kjaersgard IVH Jessen F, Jacobsen C (2007) Protein and lipid oxidation during frozen storage of rainbow trout (Oncorhynchus mykiss). J Agri Food Chem 55(20): 8118-8125.

47. Saeed S, Howell NK (2002) Effect of lipid oxidation and frozen storage on muscle proteins of Atlantic mackerel (Scomber scombrus). J Sci Food Agri 82(5): 579-586.

48. Dalle-Donne I, Rossi R, Giustarini D, Milzani A, Colombo R (2003) Protein carbonyl group as biomarkers of oxidative stress. Clin Chim Acta 329(1-2): 23-38.

49. Vuorela S, Salminen H, Makela M, Kivikari R, Karonen M, et al. (2005) Effect of plant phenolics on protein and lipid oxidation in cooked pork meat patties. J Agri Food Chem 53(22): 8492-8497. 
50. Siebert KJ, Troukhanova NV, Lynn PY (1996) Nature of polyphenol protein interactions. J Agri Food Chem 44(1): 80-85.

51. Cao N, Fu Y, He J (2007) Mechanical properties of gelatin films crosslinked, respectively, by ferulic acid and tannic acid. Food Hydrocolloid 21(4): 575-584.

52. De Freitas V, Mateus N (2001) Structural features of procyanidin interactions with salivary proteins. J Agri Food Chem 49(2): 940-945.

53. Leuschner RG, Ielsch V (2003) Antimicrobial effects of garlic, clove and red hot chili on Listeria monocytogenes in broth model systems and soft cheese. Int J Food Sci Nutri 54(2): 127-133.

54. Benjakul S, Seymour TS, Morrissey MT, An H (1997) Physicochemical changes in Pacific whiting muscle proteins during iced storage. J Food Sci 62(4): 729-733.

55. Kroll J, Rawel HM, Rohn S (2003) Reactions of plant phenolics with food proteins and enzymes under special consideration of covalent bonds. Food Sci Technol Res 9: 205-218.

56. Lanier TC, Hart K, Martin RE (1991) A manual of standard methods for measuring and specifying the properties of surimi. National Fisheries Institute, Washington, USA.

57. Samouris GI, Bampidis VA, Sossidou E, Zantopoulos N (2007) Lipid oxidation and color change in cooked turkey products during refrigerated storage. J Food Sci 67(2): 582-585.

Your next submission with Juniper Publishers will reach you the below assets

- Quality Editorial service

- Swift Peer Review

- Reprints availability

- E-prints Service

- Manuscript Podcast for convenient understanding

- Global attainment for your research

- Manuscript accessibility in different formats

(Pdf, E-pub, Full Text, Audio)

- Unceasing customer service

Track the below URL for one-step submission https://juniperpublishers.com/online-submission.php 